\title{
Effects of so-called "environmentally friendly" agrochemicals on the harlequin ladybird Harmonia axyridis (Coleoptera: Coccinelidae)
}

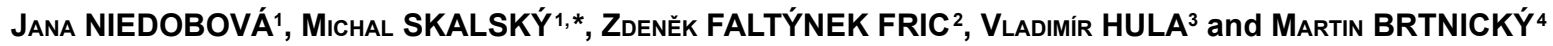 \\ ${ }^{1}$ Research and Breeding Institute of Pomology Holovousy Ltd., Holovousy 129, 50801 Hořice, Czech Republic; \\ e-mails: naaudia@seznam.cz, michal.skalsky@vsuo.cz \\ ${ }^{2}$ Biology Centre of the Czech Academy of Sciences, Institute of Entomology, Branisovska 31, 370 05 Ceske Budejovice, \\ Czech Republic; e-mail: fric@entu.cas.cz \\ ${ }^{3}$ Department of Zoology, Fisheries, Hydrobiology and Apiculture, Faculty of AgriSciences, Mendel University in Brno, \\ Zemědělská 1, 61300 Brno, Czech Republic; e-mail: hula@mendelu.cz
}

${ }^{4}$ Mendel University in Brno, Zemědělská 1, 61300 Brno, Czech Republic; e-mail: martin.brtnicky@seznam.cz

Key words. Coleoptera, Coccinellidae, Harmonia axyridis, beneficial arthropod, integrated pest management, lethal effect, agrochemicals, Prev B2, Boundary SW

\begin{abstract}
A variety of plant protection products and other agrochemicals are used in agro-ecosystems. Products approved for integrated pest management (IPM) or organic farming should have minimal negative side effects on beneficial insects. The Asian harlequin ladybird Harmonia axyridis (Pallas, 1773) (Coleoptera: Coccinellidae) has become a widespread and important generalist predator of certain agricultural pests, mainly aphids, throughout Europe. We studied the effects of two agrochemicals, Boundary SW ${ }^{\circledR}$ (auxiliary plant protection product) and Prev B2 ${ }^{\circledR}$ (foliar boron fertilizer), usually regarded as "environmentally friendly" and known to have insecticidal side effects against some fruit and vegetable pests (e.g., aphids, spider mites, weevils), on the last larval instar and adults of Harmonia axyridis. The conventional organophosphate insecticide Reldan $22^{\circledR}$ was used as a chemical standard for evaluating the lethal effect, because this product is usually effective against a broad spectrum of insects, and indeed was immediately lethal for both the adults and larvae of this species. However, whereas Prev B2 ${ }^{\circledR}$ had no effect, adult ladybirds sprayed with Boundary SW ${ }^{\circledR}$ survived only for up to $25 \mathrm{~h}$ and also none of the larvae completed their development. Thus, although our experiments were not made under natural conditions, the use of Boundary SW ${ }^{\circledR}$ cannot be recommended for IPM and organic farming in terms of safeguarding insect predators such as Harmonia axyridis until further more detailed testing.
\end{abstract}

\section{INTRODUCTION}

Crop protection is usually based on a broad range of chemical pesticides and other agrochemicals, such as auxiliary plant protection products, adjuvants and fertilizers, which can have insecticidal side effects on beneficial arthropods (Desneux et al., 2007; Evans et al., 2010; Korenko et al., 2016; Niedobová et al., 2016). Beneficial arthropods, such as predators are able to significantly suppress pest populations in agro-ecosystems (Greenstone et al., 2010, Suenaga \& Hamamura, 2015).

Ladybirds (Coleoptera: Coccinellidae) are very important biological control agents as their prey includes important pest taxa (Gao et al., 2009; Harwood et al., 2009; Greenstone et al., 2010; Moser et al., 2011; Aslam et al., 2013; Zilnik \& Hagler, 2013). One of the currently most widespread and abundant species of the family Coccinellidae is the harlequin ladybird, Harmonia axyridis, a generalist predator that inhabits a wide range of natural as well as agricultural habitats (Brown \& Miller, 1998; Seo \& Youn, 2000; Koch, 2003; Snyder et al., 2004; Brown et al., 2011). This species may successfully regulate the abundance of aphids, coccids, and many other pests. It is able to suppress black cherry aphid Myzus cerasi (Fabricius, 1775), pear psylla Cacopsylla pyri (Linnaeus, 1761), apple aphid Aphis pomi (de Geer, 1773), mealy plum aphid Hyalopterus pruni (Geoffroy, 1762), and green peach aphid Myzus persicae (Sulzer, 1776) in orchards (Nedvěd, 2014). Because of its success in pest suppression, this beetle has been introduced as a biocontrol agent around the world (Kuroda \& Miura, 2003; LaRock et al., 2003; Pervez \& Omkar, 2006; Kinawy et al., 2008; Brown et al., 2011; Adachi-Hagimori et al., 2011). However, besides the role of this species as a biocontrol agent, the establishment of $H$. axyridis outside its native Asian range raised concerns about its possible negative effects on native insects (Brown \& Roy, 2018; Masetti et al., 2018).

Ladybirds are vegetation-dwelling and active during the day (Hodek \& Honěk, 1996; Seo \& Youn, 2000; Nedvěd, 2014). They may therefore come into direct contact with various plant protection products in agro-ecosystems. Harlequin ladybirds are also used as a model organism for studying the effects of pesticides on beneficial arthropods (Vincent et al., 2000; Michaud, 2002;

\footnotetext{
* Corresponding author; e-mail: michal.skalsky@vsuo.cz
} 
James, 2003; Youn et al., 2003; Galvan et al., 2006). Coccinellid susceptibility to plant protection products varies with species, type of treatment (Theling \& Croft, 1988; Biondi et al., 2011) and developmental stage (Banken \& Stark, 1997; Youn et al., 2003).

Risk assessments are required for pesticides (Desneux et al., 2007), but tests of agrochemicals, which could have insecticidal side effects on beneficial arthropods, are not required. Insecticidal side effects are referred to on product labels of some fertilizers, surfactants or agents promoting resistance in plants (e.g., ICAS, 2017; Biocont Laboratory, 2018). These products contain substances which are able to suppress some pests, but fall under fertilizer legislation [Council Regulation (EC) No. 834/2007 of 28 June 2007 on organic production and labelling of organic products and repealing Regulation (EEC) No. 2092/91] and are officially sold as fertilizers. Although the proposed "Regulation of the European Parliament and of the Council laying down rules on the making available on the market of CE marked fertilising products and amending Regulations (EC) No. 1069/2009 and (EC) No. 1107/2009 COM(2016) 0157 final - 2016/0084 (COD)" is in the legislative process at present (Eur-Lex, 2017), there is currently no effective legislation in Europe dealing with the evaluation of these auxiliary plant protection products.

This preliminary study tests the insecticidal activity of two agrochemicals regarded as "environmentally friendly" for larvae and adults of the widespread generalist predator $H$. axyridis. These agrochemicals were selected on the basis of their current and potential use in agro-ecosystems. Boundary $\mathrm{SW}^{\circledR}$ is an auxiliary plant protection product containing biological ingredients (seaweed and succulent extracts), which increase the resistence of plants (ICAS, 2017) and also have insecticidal side effects against sucking and chewing pests such as aphids, spider mites, weevils and psyllids (Kloutvorová et al., 2015; Skalský, 2017). Prev $\mathrm{B} 2^{\circledR}$ is a boron foliar fertilizer, which contains orange oil (Biocont Laboratory, 2018). Prev B2 ${ }^{\circledR}$ is highly efficient against apple aphid (Skalský, 2015). Orange oil affects many species of insects (Sheppard, 1984; Raina et al., 2007) including some beneficial arthropods (Niedobová et al., 2016).

\section{MATERIALS AND METHODS}

\section{Compounds and species studied}

Fourth-instar larvae and adults of Harmonia axyridis were used for studying the effects of two agrochemicals regarded as "environmentally friendly" but with insecticidal side effects: Boundary $\mathrm{SW}^{\circledR}$ (producer ICAS SLR, Italy) and Prev B2 ${ }^{\circledR}$ (producer Oro Agri International Ltd.). A broad spectrum insecticide (Reldan $22^{\circledR}$ ) and a control sprayed only with water were used for comparison. Reldan $22^{\circledR}$ is a broad-spectrum organophosphate insecticide and its active ingredient, chlorpyrifos-methyl, is also used to protect various crops in many European countries, as well as in Australia and the United States (Li at al., 2015; Miclea et al., 2016; Pesticide Properties DataBase, 2018). Information on all the plant protection products tested, their type, specification, distributor, active ingredients and use is listed in Table 1.

\section{Collection and maintenance of Harmonia axyridis}

Both adults and larvae were collected by hand on 12 June 2017 on apple trees in orchards of the Research and Breeding Institute of Pomology Holovousy (RBIP), Holovousy, Czech Republic. The plots where insects were collected were not previously treated with agrochemicals. Adults and larvae were placed separately in Petri dishes ( $85 \mathrm{~mm}$ in diameter) with filter paper on the bottom and reared under laboratory conditions at $22 \pm 1{ }^{\circ} \mathrm{C}$ with a $16 \mathrm{~L}$ : $8 \mathrm{D}$ photoperiod for a week prior to the experiment. Adults and larvae were fed ad libitum with apple aphid (Aphis pomi) each day and water was provided on a piece of cotton pad. Only larvae of the last (fourth) instar were used in the experiments. Larvae and adults were identified following Nedvěd $(2014,2015)$.

\section{Laboratory testing}

Larvae and adults were randomly divided into four treatment groups. Each group consisted of 32 individuals and each individual was placed separately in a petri dish (total $\mathrm{N}$ adults $=128$, total $\mathrm{N}$ larvae $=128$ ). Each individual (larvae of last instar or adult) was used only once.

The agrochemicals were diluted in distilled water in accordance with the manufacturers' instructions: $0.5 \%$ for Prev-B2 ${ }^{\circledR}, 4 \%$ for Boundary $\mathrm{SW}^{\circledR}$ and $0.27 \%$ for Reldan $22^{\circledR}$. The control group was exposed only to distilled water. Treatments were applied by direct spraying following the recommendation for field application. A pharmaceutical pump sprayer with precisely measured aerosol dose of $0.05 \mathrm{ml}$ was used for spraying individuals in Petri dishes from a distance of $15 \mathrm{~cm}$. The amount of treatment solution sprayed on a Petri dish with an individual was recalculated from field rates to the area of the Petri dish. Each Petri dish was marked with an exclusive code for the treatment. After treatments adults and larvae were fed and provided with water as previously. Mortality was determined 1, 10, 24, 34, 48, 58 and $72 \mathrm{~h}$ after treatment. The criterion for death was immobility of individuals when stimulated with a fine brush.

\section{Data analysis}

Differences in the proportions that survived the effects of insecticides were analysed using Survival Analyses (package "survival" in $\mathrm{R} x 64$ 3.3.1). We used the maximum time for which the individuals survived as the time variable; individual treatments and the data were censored for the dead or alive status. We calculated a Kaplan-Meier estimate of survival with weighted log-rank tests $($ rho $=0)$. We ran the analyses separately for effects of the treatments on adults and larvae of the last instar.

\section{RESULTS}

\section{Adults}

The survival of adults $H$. axyridis (Fig. 1) was affected not only by the conventional insecticide Reldan $22^{\circledR}$, but also by one of the tested "environmentally friendly" agrochemicals, Boundary SW ${ }^{\circledR}$. The differences in the proportions that survived in the four treatments were strongly significant $\left(X^{2}=86.9, \mathrm{df}=3, p<<0.001\right)$.

Table 1. Specifications of three plant protection products, two regarded as "environmentally friendly" and one conventional pesticide, used in this study of their possible effects on Harmonia axyridis, with an overview of distributor, active ingredient and target crops.

\begin{tabular}{llllll}
\hline Trade name & Type & Specification & Distributor & Active ingredient & Use \\
\hline Boundary SW & $\begin{array}{l}\text { Environmentally Auxiliary plant } \\
\text { friendly }\end{array}$ & protection product & ICAS srl & $\begin{array}{l}\text { Fermented seaweed extract } \\
\text { and succulent extract }\end{array}$ & $\begin{array}{l}\text { Fruits, vegetables, crops in } \\
\text { greenhouses }\end{array}$ \\
\hline Prev-B2 $^{\circledR}$ & $\begin{array}{l}\text { Environmentally } \\
\text { friendly }\end{array}$ & Boron fertilizer & $\begin{array}{l}\text { Oro Agri } \\
\text { International Ltd. }\end{array}$ & $\begin{array}{l}\text { Ethanolamine borate }(2.1 \%), \\
\text { Orange oil (4.2\%) }\end{array}$ & Fruits, vegetables, rape, cereals \\
\hline Reldan 22 & Conventional & $\begin{array}{l}\text { Broad-spectrum } \\
\text { insecticide }\end{array}$ & $\begin{array}{l}\text { Dow AgroSciences } \\
\text { Ltd. }\end{array}$ & $\begin{array}{l}\text { Chlorpyrifos-methyl } \\
(225 \mathrm{~g} / \mathrm{ll})\end{array}$ & $\begin{array}{l}\text { Fruits, cruciferous vegetable } \\
\text { seedlings, rape, mustard, grain } \\
\text { crops, storage pests }\end{array}$ \\
\hline
\end{tabular}


Survival of larvae and adults of Harmonia axyridis exposed to plant protection products
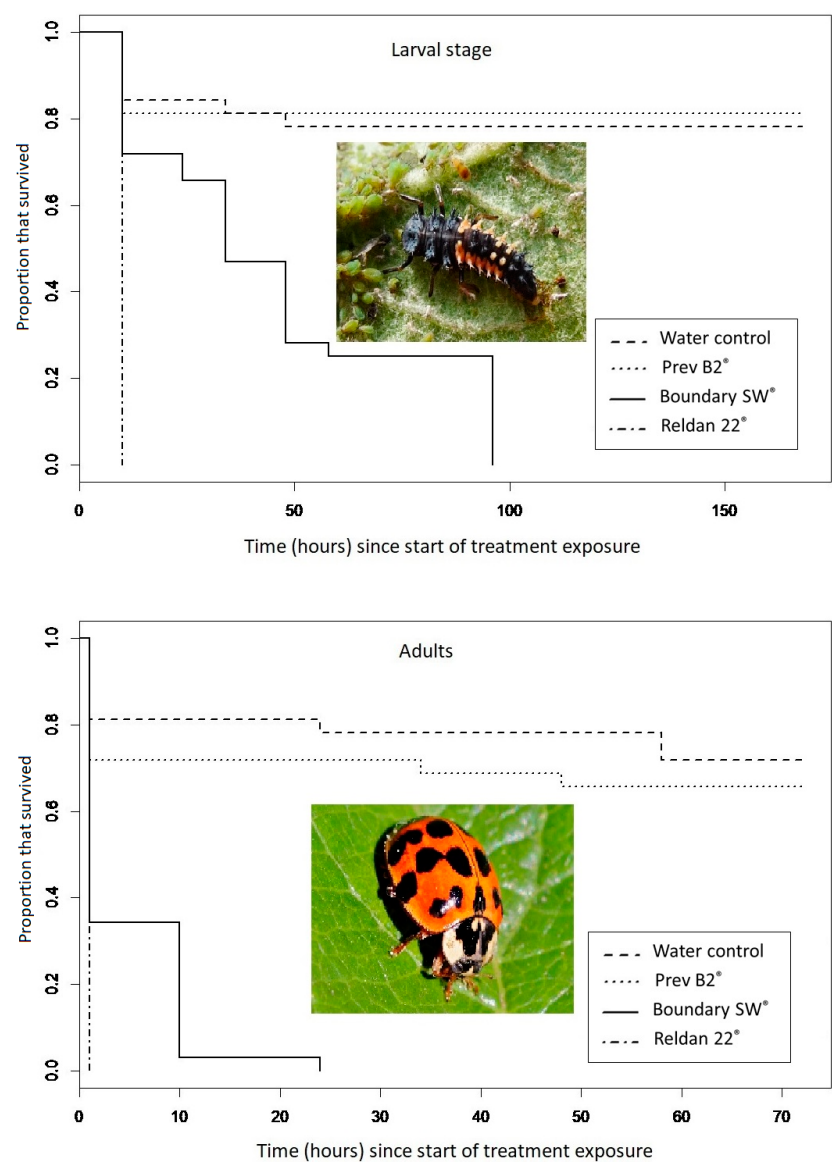

Fig. 1. Proportion of the larvae (top) and adults (bottom) of the lady beetle $H$. axyridis that survived after exposure to two "environmentally friendly" (Boundary SW ${ }^{\circledR}$ and Prev B2 ${ }^{\circledR}$ ) and one conventional pesticide (Reldan $22^{\circledR}$ ) plant protection products plus a control (distilled water) treatment. The $x$-axis is the number of hours from start of exposure and $y$-axis proportion surviving.

The Prev-B2 ${ }^{\circledR}$ and control treatments resulted in similar curves with only a few deaths and had no effect on the survival of the adult ladybirds, whereas the conventional insecticide Reldan $22^{\circledR}$ resulted in immediate death on spraying. Individuals exposed to Boundary SW ${ }^{\circledR}$ survived only for up to $25 \mathrm{~h}$.

\section{Larval stage}

The results of the treatments of larvae (Fig. 1) were similar to those for adults. There were significant differences in survival $\left(X^{2}=106, \mathrm{df}=3, p<<0.001\right)$, with no differences between the control and Prev-B2 ${ }^{\circledR}$ treatments, immediate death after treatment with Reldan $22^{\circledR}$ and limited survival when treated with Boundary $\mathrm{SW}^{\circledR}$.

\section{DISCUSSION}

Even though none of the tests were carried out under natural conditions, the present study demonstrated that different plant protection products approved for IPM and organic farming can vary widely in their adverse effects on larvae and adults of $H$. axyridis. Although the method used (direct spraying in petri dishes with no possibility of escape) may represent the "maximum challenge" scenario for the experimental insects, no statistically significant decrease in survival of larvae or adults was recorded when treated with Prev-B $2^{\circledR}$. Kolařík (2017) also reports that contact with the residue of this product has no lethal effect on the bumblebee Bombus terrestris. However, this study did not address possible sub-lethal effects. Agrochemicals can in various ways impair the performance of individuals that survive exposure to a given treatment (Desneux et al., 2007; Niedobová et al., 2016; Depalo et al., 2017). Prev-B2 ${ }^{\circledR}$ contains orange oil, which is reported to be toxic for the Formosan subterranean termite (Coptotermes formosanus Shiraki, 1909), house fly (Musca domestica Linnaeus, 1758) and red fire ant (Solenopsis invicta Buren, 1972) (Sheppard, 1984; Raina et al., 2007). Orange oil is also a component of the non-ionic surfactant Wetcit ${ }^{\mathbb{R}}$, and Niedobová et al. (2016) report that Wetcit ${ }^{\circledR}$ affects the predatory activity of the wolf spider Pardosa agrestis (Westring, 1861).

In contrast, direct contact with the "environmentally friendly" agrochemical Boundary $\mathrm{SW}^{\circledR}$ is lethal to both larvae and adults of Harmonia axyridis, although death occurrs much later than when similarly treated with Reldan 22 (Fig. 1). Nevertheless, Boundary $\mathrm{SW}^{\circledR}$ has been approved for IPM and organic farming [Council Regulation (EC) No. 834/2007 of 28 June 2007 on organic production and labelling of organic products and repealing Regulation (EEC) No. 2092/91]. This product is also approved by the American Regulation National Organic Program (Groupe ECOCERT, 2018). Boundary SW ${ }^{\circledR}$ contains liquid extract of fermented seaweed supplemented with an extract from succulents (ICAS, 2017). This product has proved $100 \%$ effective against leaf-rolling weevils Anthonomus pomorum (Linnaeus, 1758) and Tatianaerhynchites aequatus (Linnaeus, 1767) after $24 \mathrm{~h}$ when direct spraying is used (Skalský, 2017). Taskin et al. (2014) report that spraying the scale insect Planococcus ficus (Signoret, 1875) with this product results in mean mortalities of less than $20 \%$ after $25 \mathrm{~h}$. We could find only a few studies on Boundary $\mathrm{SW}^{\circledR}$ and its effects on beneficial arthropods. Kolařík (2017) reports that contact with residues of commonly applied field doses of Boundary $\mathrm{SW}^{\circledR}$ did not affect the mortality of Bombus terrestris (Linnaeus, 1758) under laboratory conditions. Further studies under natural conditions are required to assess the ecological relevance of our preliminary results showing negative effects of Boundary $\mathrm{SW}^{\circledR}$ on Harmonia axyridis. However, Boundary $\mathrm{SW}^{\circledR}$ is primarily used as a general growth promotor for crops (ICAS, 2017) and therefore it is very likely that many beneficial arthropods come into contact with this product in different agro-ecosystems.

A number of other studies on biopesticides and environmentally friendly agricultural materials also indicate they adversely affect beneficial organisms. Biondi et al. (2011) note lethal and sub-lethal effects of so-called biopesticides on the generalist predatory bug Orius laevigatus (Fieber, 1860). Kang et al. (2007a) report that many environmental friendly agricultural materials are toxic for the important spider mite predator Phytoseiulus persimilis Athias-Henriot, 1957. Kang et al. (2007b) also tested environmentally friendly agricultural materials on developmental stages of $H$. axyridis and they state that products containing plant extracts might reduce its percentage egg hatch. Pavela et al. (2013) who studied the possibilities of using an extract of the seed of Angelica archangelica as a biopesticide against the aphid pest Acyrthosiphon pisum (Harris, 1776) also report its effect on the eggs, larvae and adults of $H$. axyridis. They record slight toxicity for the larvae of the 2 nd-3rd instar at high concentration after direct contact. To sum up, the above results (including ours) indicate that many agrochemicals, which are not listed as pesticides (and a risk assessment of such products for beneficial arthropods is not required) but have (or may have) insecticidal side effects, should be tested for pesticidal effects against beneficial arthropods (e.g., Eur-Lex, 2017).

ACKNOWLEDGEMENTS. This work was supported by the Ministry of Agriculture of the Czech Republic, National Agency 
for Agricultural Research (NAZV), project QK1710200 and QJ1510352; by the Ministry of Education, Youth and Sports, project LO1608 - Pomology Research Center within the National Sustainable Development Strategy.

\section{REFERENCES}

Adachi-Hagimori T., Shibao M., Tanaka H., Seko T. \& Miura K. 2011: Control of Myzus persicae and Lipaphis erysimi (Hemiptera: Aphididae) by adults and larvae of a flightless strain of Harmonia axyridis (Coleoptera: Coccinellidae) on nonheading Brassica cultivars in the greenhouse. - Biocontrol 56: $207-2013$.

Aslam M., Ruby T., Ghaffar A., Faroog Z., Hussain T. \& Rafay M. 2013: PCR-based detection of aphids in the gut contents of arthropod predators. - Int. J. Agric. Biol. 15: 398-400.

BANKEn J. \& Stark J. 1997: Stage and age influence on the susceptibility of Coccinella septempunctata (Coleoptera: Coccinellidae) after direct exposure to Neemix, a neem insecticide. - J. Econ. Entomol. 90: 1102-1105.

Biocont Laboratory 2018: Prev-B2. URL: http://www.biocont.cz/data/pr_produkty/8/files_cs/prevb2_etiketa_a4_platna_2013.pdf (last accessed 17 Dec. 2018).

Biondi A., Desneux N., Siscaro G. \& Zappaalà L. 2011: Using organic-certified rather than synthetic pesticides may not be safer for biological control agents: Selectivity and side effects of 14 pesticides on the predator Orius laevigatus. - Chemosphere 87: 803-812.

Brown M.W. \& MilLER S.S. 1998: Coccinellidae (Coleoptera) in apple orchards of eastern West Virginia and the impact of invasion by Harmonia axyridis. — Entomol. News 109: 143-151.

Brown P.M.J. \& Roy H.E. 2018: Native ladybird decline caused by the invasive harlequin ladybird Harmonia axyridis: evidence from a long-term field study. — Insect Conserv. Div. 11: 230-239.

Brown P.M.J., Thomas C.E., Lombaert E., Jeffries D.L., Estoup A. \& HandLEy L.J.L. 2011: The global spread of Harmonia axyridis (Coleoptera: Coccinellidae): distribution, dispersal and routes of invasion. - Biocontrol 56: 623-641.

Depalo L., Lanzoni A., Masetti A., Pasqualini E. \& Burgio G. 2017: Lethal and sub-lethal effects of four insecticides on the aphidophagous coccinellid Adalia bipunctata (Coleoptera: Coccinellidae). - J. Econ. Entomol. 110: 2262-2671.

Desneux N., Decourtye A. \& Delpuech J.M. 2007: The sublethal effects of pesticides on beneficial arthropods. - Annu. Rev. Entomol. 525: 81-106.

Eur-Lex 2017: Proposal for a Regulation of the European Parliament and of the Council Laying Down Rules on the Making Available on the Market of CE Marked Fertilising Products and Amending Regulations (EC) No 1069/2009 and (EC) No 1107/2009 [COM(2016) 0157 final - 2016/0084 (COD). URL: http://eur-lex.europa.eu/search. html?qid=1463149313434\&PROC_NUM=0084\&DB INTER_CODE_TYPE $=$ OLP\&type $=$ advanced\&PROC ${ }_{-}^{-}$ $\mathrm{ANN}=2016 \&$ lang $=$ en (last accessed 20 Dec. 2017).

Evans S.E., Shaw E.M. \& Rypstra A.L. 2010: Exposure to a glyphosate-based herbicide affects agrobiont predatory arthropod behaviour and long-term survival. - Ecotoxicology 19: 1249-1257.

Galvan T.L., Koch R.L. \& Hutchison W.D. 2006: Toxicity of indoxacarb and spinosad to the multi-colored Asian lady beetle, Harmonia axyridis (Coleoptera: Coccinellidae), via three routes of exposure. - Pest. Manag. Sci. 62: 797-804.

Gao S.J., Zhou X.R., Pang B.P., van Loon J.J.A. \& Zhao G.Q. 2009: Development and use of a monoclonal antibody to de- tect semi-digested proteins of the English grain aphid, Sitobion avenae, in the guts of ladybird beetle predators. - Entomol. Exp. Appl. 133: 193-198.

Greenstone M.H.L., Szendrei Z., Payton M.E., Rowley D.L., Coudron T.C. \& Weber D.C. 2010: Choosing natural enemies for conservation biological control: use of the prey detectability half-life to rank key predators of Colorado potato beetle. - Entomol. Exp. Appl. 136: 97-107.

Groupe ECOCERT 2018: Imputs.bio. Suitable Products for Organic Farming. URL: http://ap.ecocert.com/intrants/fournisseur.php?1=en\&recherche_produit $=\& \mathrm{id}=850 \&$ recherche categorie $=0 \&$ recherche_statut $=1,0,0,0,0$. (last accessed $1 \overline{8}$ April 2018).

Harwood J.D. Yoo H.J.S., Greenstone M.H., Rowle D.L. \& O'NeIL R.J. 2009: Differential impact of adults and nymphs of a generalist predator on an exotic invasive pest demostrated by molecular gut-content analysis. - Biol. Invas. 11: 895-903.

Hodek I. \& HonĚK A. 1996: Ecology of Coccinellidae. Kluwer Academic Publishers, Dordrecht, 464 pp.

ICAS 2017: Boundary SW. URL: http://www.icasinternational.it/ index.php?option $=$ com_k2\&view $=$ item\&layout $=i$ tem $\& i d=16$ $5 \&$ Itemid $=318 \&$ lang=en (last accessed 31 Oct. 2017).

JAMES D.G. 2003: Pesticide susceptibility of two coccinellids (Stethorus punctum picipes and Harmonia axyridis) important in biological control of mites and aphids in Washington hops. - Biocontr. Sci. Technol. 13: 253-259.

Kang E.-J., Kang M.-K., Lee H.-J., Lee D.-H., SeoK H.-B., Kim D.-A., Gil M.-L., Seo M.-J., Yu Y.-M. \& Youn Y.-N. 2007a: Effects of environment friendly agricultural materials to each developmental stages of Harmonia axyridis (Coleoptera: Coccinellidae) in the laboratory. - Kor. J. Appl. Entomol. 46: 97-107.

Kang M.-K., Kang E.-J., Lee H.-J., Lee D.-H., Seok H.-B., Kim D.-A., Gil M.-L., Seo M.-J., Yu Y.-M. \& Youn Y.-N. 2007b: Effects of environment friendly agricultural materials to Phytoseiulus persimilis (Acari: Phytoseiidae) in the laboratory. Kor. J. Appl. Entomol. 46: 87-95.

Kinawy M.M., Al-Waili H.M. \& Almandhari A.M. 2008: Review of the successful classical biological control programs in Sultanate of Oman. - Egypt. J. Biol. Pest Contr. 18: 1-10.

Kloutvorová J., Skalský M., OuředníčKová J., Hortová B., VejRažKa K., Kolařík P., Komzáková O., Titěra D., Vinšová H., Horna A. ET AL. 2018: [Methodology of Fruit Pest Control with Emphasis on Insect Pollinators]. Research and Breeding Institute of Pomology, Holovousy, 116 pp. [in Czech].

Koch R.L. 2003: The multicolored Asian lady beetle, Harmonia axyridis: A review of its biology, uses in biological control, and non-target impacts. - J. Insect Sci. 3: 32, 16 pp.

KolAří P. 2017: [Evaluation of natural bumblebee sensitivity to pesticide active substances in 2016.] - Agromanuál 2: 54-55 [in Czech].

Korenko S., Niedobová J., KoláŘová M., Hamouzová K., Kysilková K. \& Michalko R. 2016: The effect of eight common herbicides on the predatory activity of the agrobiont spider Pardosa agrestis. - Biocontrol 61: 507-517.

Kuroda T. \& Miura K. 2003: Comparison of the effectiveness of two methods for releasing Harmonia axyridis (Pallas) (Coleoptera: Coccinellidae) against Aphis gossypii Glover (Homoptera: Aphididae) on cucumbers in a greenhouse. - Appl. Entomol. Zool. 38: 271-274.

LaRock D.R., Mirdad Z., Ellington J.J., Carrillo T. \& SouthWARD M. 2003: Control of green peach aphids Myzus persicae (Homoptera: Aphididae) with lady beetles Harmonia axyridis on Chile Capsicum annum (Coleoptera: Coccinellidae) in the greenhouse. - Southw. Entomol. 28: 249-253. 
Li D., Huang Q., Lu M., Zhang L., YAng Z., Zong M. \& TAO L. 2015: The organophosphate insecticide chlorpyrifos confers its genotoxic effects by inducing DNA damage and cell apoptosis. - Chemosphere 135: 387-393.

Masetti A., Magagnoli S., Lami F., Lanzoni A. \& Burgio G. 2018: Long term changes in the communities of native ladybirds in Northern Italy: impact of the invasive species Harmonia axyridis (Pallas). - BioControl 63: 665-675.

Michaud J.P. 2002: Relative toxicity of six insecticides to $C y$ cloneda sanguinea and Harmonia axyridis (Coleoptera: Coccinellidae). - J. Entomol. Sci. 37: 83-93.

Miclea I., Cosma D., Zăhan M., Perneș A. \& Miclea V. 2016: In vitro evaluation of the Reldan $22^{\circledR}$ insecticide effects on swine oocyte maturation. - Bull. Univ. Agric. Sci. 73: 144-149.

Moser S.E., KajtTa Y., Harwood J.D. \& Obracki J.J. 2011: Evidence for utilization of Diptera in the diet of field-collected coccinellid larvae from an antibody-based detection system. Biol. Contr. 58: 248-254.

NedvĚD O. 2014: [Asian Lady Beetle (Harmonia axyridis) a Helper in Biological Pest Control or Threat to Biodiversity? Certified Practice Methodology]. South Bohemian University, České Budějovice, 67 pp. [in Czech].

NedvĚD O. 2015: Ladybird Beetles (Coccinellidae). Academia, Prague, $304 \mathrm{pp}$.

Niedobová J., Hula V. \& Michalko R. 2016: Sublethal effect of agronomical surfactants on the spider Pardosa agrestis. - Environ. Pollut. 213: 84-89.

Pavela R., ŽAbKa R., VRchotová N., TŘísKa J. \& Kazda J. 2013 Selective effects of the extract from Angelica archangelica L. against Harmonia axyridis (Pallas) - an important predator of aphids. - Indust. Crop. Prod. 51: 87-92.

Pervez A. \& OmKar 2006: Ecology and biological control application of multicoloured Asian ladybird, Harmonia axyridis: a review. - Biocontr. Sci. Technol. 16: 111-128.

Pesticide Properties DataBase 2018: Chlorpyrifos-methyl. URL: http://sitem.herts.ac.uk/aeru/ppdb/en/Reports/155.htm (last accessed 27 Sept. 2018).

Raina A., Bland J., Doolittle M., Lax A., Boopathy R. \& FolKINS M. 2007: Effect of orange oil extract on the formosan subterranean termite (Isoptera: Rhinotermitidae). $-J$. Econ. Entomol. 100: 880-885.
Seo M.J. \& Youn Y.N. 2000: The Asian ladybird, Harmonia axyridis, as biological control agents: I. Predacious behavior and feeding ability. — Kor. J. Appl. Entomol. 39: 59-71.

SHEPPARD D.C. 1984: Toxicity of citrus peel liquids to the house fly and red imported fire ant. - J. Agric. Entomol. 1: 95-100.

Snyder W.E., Ballard S.N., Yang S., Clevenger G.M., Miller T.D., Ahn J.J., Hatten T.D. \& Berryman A.A. 2004: Complementary biocontrol of aphids by the ladybird beetle Harmonia axyridis and the parasitoid Aphelinus asychis on greenhouse roses. - Biol. Contr. 30: 229-235.

SKALSKÝ M. 2015: [Evaluating the efficacy of products authorized for organic growing systems for apple aphid.] — Zahradnictvi 14(5): 16-18 [in Czech].

SKALSKÝ M. 2017: [Effectiveness of selected agents against weevil pests.] - Zahradnictví 16(2): 20-23 [in Czech].

Suenaga H. \& Hamamura T. 2015: Effects of manipulated density of the wolf spider, Pardosa astrigera (Araneae: Lycosidae), on pest populations and cabbage yield: A field enclosure experiment. - Appl. Entomol. Zool. 50: 89-97.

Taskin E., Lamaj F., Verrastro V. \& Baldacchino F. 2014: Laboratory efficacy of natural substances on Planococcus ficus (Sign.) and their impact on its two natural enemies. In Kovačević D. (ed.): Proceedings of the Fifth International Scientific Agricultural Symposium "Agrosym 2014", Jahorina, Bosnia and Herzegovina, October 23-26, 2014. University of East Sarajevo, pp. 483-490.

Theiling K.M. \& Croft B.A. 1988: Pesticide side effects on arthropod natural enemies: a database summary. - Agr. Ecosyst. Environ. 21: 191-218.

Vincent C., Ferram A., Guige L., Gambier J. \& Brun J. 2000: Effects of imidacloprid on Harmonia axyridis (Coleoptera: Coccinellidae) larval biology and locomotory behaviour. - Eur. J. Entomol. 97: 501-506.

Youn Y.N., Seo M.J., Shin J.G., JANG C. \& Yu Y.M. 2003: Toxicity of greenhouse pesticides to multicolored Asian lady beetles, Harmonia axyridis (Coleoptera: Coccinellidae). - Biol. Contr. 28: $164-170$.

Zilnik G. \& Hagler J.R. 2013: An immunological approach to distinguish arthropod viviphagy from necrophagy. - BioControl 58: 807-814.

Received January 10, 2019; revised and accepted May 15, 2019 Published online May 31, 2019 